\title{
Infiltration parameters for rangeland soils
}

\author{
W.J. RAWLS, D.L. BRAKENSIEK, AND M.R. SAVABI
}

\begin{abstract}
Important to the management of rangelands is knowledge of the water intake properties of their soils and the effect of soil surface and canopy cover. Using a data base of rangeland infiltration runs covering a wide range of soll and cover conditions, a procedure incorporating the effects of soil properties, soil surface cover, and vegetative canopy on the Green-Ampt hydraulic conductivity parameter was developed. Test results indicate that the estimated Green-Ampt parameters provided good predictions of the mean final infiltration rates and volumes for a variety of soil-cover situations.
\end{abstract}

\section{Key Words: Green-Ampt, infiltration rates, soil properties}

The importance of ground and canopy cover on rangeland infiltration characteristics has long been recognized (Gifford 1984). Generally, it has been shown that as ground cover or canopy cover increase, infiltration amounts increase while increases in bare ground decreases infiltration amounts (Gifford 1984). Most recently Hutten and Gifford (1988) showed that Green-Ampt parameters estimated from soil texture data alone do not adequately model rangeland infiltration. Mehan (1986) showed that infiltration increases with increases in surface rock for a range of soil textures. Also, Lane et al. (1987) conducted infiltration studies on 5 soils in Arizona and Nevada where rainfall simulation experiments were run on plots with natural cover canopy removed and bare plots where the canopy and most of the surface rock and litter were removed. They found that infiltration was greatest for the natural condition, declining when canopy was removed and further declining when surface rock and litter were removed.

At present there are methods for predicting parameters for the Green-Ampt infiltration model based on soil properties (Rawls and Brakensiek, 1983, 1985); however, there is no method for incorporating the effects of rangeland ground cover and canopy cover on infiltration parameters. Therefore, it is the purpose of this paper to develop procedures for incorporating the effects of ground cover and canopy caver into the Green-Ampt infiltration parameters, which may alleviate some of the problems identified by Hutten and Gifford (1988).

The Green-Ampt infiltration rate equation is

$$
f=K \quad\left(\frac{1+\left(\phi_{c}-A S W\right) \Psi_{f}}{F}\right)
$$

and its integrated form is

$$
\mathrm{K}(\mathrm{T})=\mathrm{F}-\left(\phi_{\mathrm{c}}-\mathrm{ASW}\right) \Psi_{t} \ln \left(1+\frac{\mathrm{F}}{\left(\phi_{c}-\mathrm{ASW}\right) \Psi_{t}}\right)
$$

where

$$
\begin{aligned}
\mathbf{f} & =\text { infiltration rate }(\mathrm{cm} / \mathrm{hr}) \\
\mathbf{F} & =\text { infiltration amount }(\mathrm{cm}) \\
\mathbf{T} & =\text { time }(\mathrm{hrs}) \\
\mathbf{K} & =\text { hydraulic conductivity }(\mathrm{cm} / \mathrm{hr}) \\
\Psi & =\text { wetting front capillary potential }(\mathrm{cm}) \\
\phi_{c} & =\text { corrected porosity }(\text { total porosity corrected for } \\
& \text { rocks and air) }(\mathrm{vol}) \\
\mathrm{ASW} & =\text { antecedent soil water }(\mathrm{vol})
\end{aligned}
$$

\footnotetext{
Authors are hydrologist, USDA-ARS Hydrology Laboratory, Beltsville, Md.; research engineer, Dept. of Civil Engineering. University of Maryland, College Park, Md.; and research associate, Dept. of Agronomy, University of Maryland, College Park, respectively.

Without the cooperation of those investigators who provided data given in Table 1 , this study would not have been possible.

Manuscript accepted 8 August 1988.
}

In order to predict infiltration with equations [1] or [2], the antecedent soil water (ASW) needs to be inputted and hydraulic conductivity $(K)$, wetting front capillary potential $\left(\Psi_{t}\right)$ and the porosity corrected for rocks and entrapped air $\left(\phi_{c}\right)$ need to be estimated. The following are equations used for predicting the parameters based only on soil properties:

$$
\begin{gathered}
\text { Effective Porosity ( } \left.\phi_{c}\right) \\
\phi_{c}=\phi=(\text { CFC) (EAC) }
\end{gathered}
$$

where

$$
\begin{aligned}
\phi= & \text { total porosity }(\mathrm{vol})=(2.65)-\mathrm{BD}) / 2.65 \\
\mathrm{CFC}= & \text { Correction for coarse fragments }(\text { Brakensiek et al. 1986) } \\
= & ((100-\mathrm{VCF}) / 100) \\
\mathrm{EAC}= & \text { correction for entrapped air }(\text { Rawls and Baumer } 1989) \\
= & 1.0-\left(3.8+0.00019\left(\mathrm{CL}^{2}\right)-0.337(\mathrm{SA})+0.126(\mathrm{CEC})\right. \\
& \left.\quad(\mathrm{CL})+\mathrm{OM}(\mathrm{SA} / 200)^{2}\right) / 100 \\
\mathrm{BD}= & 33 \mathrm{KPa} \text { bulk density of the fine earth soil }(<2 \mathrm{~mm}) \\
& \quad \mathrm{g} / \mathrm{cm}^{3} \\
\mathrm{OM}= & \% \text { organic matter } \\
\mathrm{CL}= & \% \text { clay } \\
\mathrm{SA}= & \% \text { sand } \\
\mathrm{CEC}= & \text { cation exchange capacity } / \% \text { clay }(\mathrm{ranges} 0-1) \\
\mathrm{VCF}= & \% \text { volume coarse fragments }(>2 \mathrm{~mm}) \text { computed from } \\
& \quad \text { Brakensiek et al. } 1986 \\
\mathrm{VCF}= & ((\text { WCF } / 2.65) * 100) /((100-\mathrm{WCF} / \mathrm{BD}+\mathrm{WCF} / 2.65)) \\
\mathrm{WCF}= & \% \text { weight of coarse fragements }(>2 \mathrm{~mm})
\end{aligned}
$$

Wetting Front Capillary Potential $\left(\Psi_{t}\right)$

$$
\Psi_{f}=\mathrm{e}^{\mathrm{x}}
$$

where $\quad x=5.34+0.185\left(C L^{2}\right)-2.484(\phi)-0.0021\left(C^{2}\right)-0.0436(\mathrm{SA})$

$(\phi)-0.6175(C L)(\phi)+0.00144\left(S^{2}\right)\left(\phi^{2}\right)-0.00855\left(C^{2}\right)$

$\left(\phi^{2}\right)-0.000013(\mathrm{CL})\left(\mathrm{SA}^{2}\right)+0.009(\phi)\left(\mathrm{CL}^{2}\right)-0.00073(\phi)$

$\left(\mathrm{SA}^{2}\right)+0.000005(\mathrm{SA})\left(\mathrm{CL}^{2}\right)+0.5003(\mathrm{CL})\left(\phi^{2}\right)$ (Rawls and

Brakensiek, 1985)

Hydraulic Conductivity (K)

$$
\mathrm{K}=\mathrm{K} \text {, (FGC) (CFC) }
$$

where $K_{\mathbf{q}}$ = saturated hydraulic conductivity (Rawls and Baumer 1989)

$$
\begin{aligned}
& =\left(\frac{\left(\phi_{c}-\theta_{r}\right)^{3}}{\left(1-\phi_{c}\right)^{2}}\right)\left(\frac{\mathrm{BD}}{\theta_{\mathrm{r}}}\right)^{2} \quad\left(.0002\left(\mathrm{C}^{2}\right)\right) \\
& \text { FGC }=\text { frozen ground correction (Lee 1983) } \\
& =2-.019 * \text { PFC } \\
& \theta_{\mathrm{r}}=\text { residual soil water (vol) (Rawls and Baumer 1989) } \\
& =0.2+0.1(\mathrm{OM})+0.25(\mathrm{CL})\left(\mathrm{CEC}^{0.45}\right)(\mathrm{BD} / 100) \\
& \text { (BD/ 100) (EAC) (CFC) } \\
& \mathrm{C}=-0.17+0.181(\mathrm{CL})-0.00000069\left(\mathrm{SA}^{2}\right)\left(\mathrm{CL}^{2}\right)- \\
& 0.00000041\left(\mathrm{SA}^{2}\right)\left(\mathrm{SI}^{2}\right) \\
& +0.000118\left(\mathrm{SA}^{2}\right)\left(\mathrm{BD}^{2}\right)+0.00069\left(\mathrm{CL}^{2}\right)\left(\mathrm{BD}^{2}\right) \\
& +0.000049\left(\mathrm{SA}^{2}\right)(\mathrm{CL})-0.000085(\mathrm{SI})\left(\mathrm{CL}^{2}\right) \\
& \mathrm{SI}=\text { percent silt. } \\
& \text { PFC }=\text { soil water at freezing }(\% \text { vol }) / \text { soil water held at } 33 \\
& \mathrm{KPa}(\% \text { vol). } \\
& \text { If } P F C \geq 1 \text {, then FGC = .1 (Lee 1983). }
\end{aligned}
$$

Brakensiek and Rawls (1983) developed a factor for reducing the saturated hydraulic conductivity for an established soil crust. The crust factor is 
$C R C=\frac{L}{\frac{L-T C}{S C}+\frac{T C}{B}}$ [6]

where CRC $=$ soil crust correction (Brakensiek and Rawls, 1983)

$\mathrm{L}=$ wetting front depth $(\mathrm{cm})$ (assume $6 \mathrm{~cm}$ )

$\mathrm{TC}=$ crust thickness $(\mathrm{cm})$ (assume $0.5 \mathrm{~cm})$

$\mathrm{B}=0.0099+0.0721(\mathrm{TC})+0.0000068\left(\mathrm{SA}^{2}\right)+0.000021$

$\left(\mathrm{SA}^{2}\right)(\mathrm{TC})-0.000315(\mathrm{SA})\left(\mathrm{TC}^{2}\right)$

$\mathrm{SC}=$ correction factor for partial saturation of the subcrust soil (Brakensiek and Rawls 1983)

Management changes are reflected in the above parameters only by changes in the bulk density of the soil.

\section{Methods}

An extensive data search was performed to compile infiltration data sets which included detailed soils, ground cover, and canopy cover information. The physical characteristics of the data sets located are summarized in Table 1.

Table 1. Summary description of data sets.

\begin{tabular}{lrl}
\hline \hline Study reference & State & General description \\
\hline Devaurs (1984) & ID & $\begin{array}{l}3 \text { soil series, grazed and non-grazed sites } \\
\text { and } 2 \text { soil water levels; 38-59\% sand; } \\
\end{array}$ \\
& $9-18 \%$ clay; bulk density $1.1-1.5 \mathrm{~g} / \mathrm{cm}^{3} ;$ \\
& $30-52 \%$ canopy; and $7-32 \%$ bare ground.
\end{tabular}

Hutten (1984) UT 5 soil sites with 2 management practices (plowed and unplowed); 25-68\% sand; $15-33 \%$ clay; bulk density $0.9-1.3 \mathrm{~g} / \mathrm{cm}^{3}$; $0.65 \%$ canopy; and $0-50 \%$ bare ground.

Lane et al. $\quad A Z \quad$ Natural, clipped and bare range cover at (1987) NV 3 sites in $A Z$ and 2 sites in NV; 66-84\% sand; $1-9 \%$ clay; $0-75 \%$ canopy; and $0-41 \%$ bare ground.

Thurow (1985) TX 27-88\% sand; $7-42 \%$ clay; bulk density $0.85-0.95 \mathrm{~g} / \mathrm{cm}^{3} ; 27-57 \%$ canopy; and $21-43 \%$ bare ground.

Ward and Wood

NM Grazing levels, pinyon-juniper mgt, sagebrush mgt and others at 3 sites; $32-90 \%$ sand; $14-33 \%$ clay; $1-90 \%$ canopy; and 3-89\% bare ground.

Williams (1969) UT 4 chained pinyon-juniper sites; $16-65 \%$ sand, 16-33\% clay; bulk density

$.9-1.6 \mathrm{~g} / \mathrm{cm}^{3} ; 0.20 \%$ canopy; and $38-97 \%$ bare ground.

Wood

NM

Dry and wet soil water levels on one range site; $29 \%$ sand; $44 \%$ clay; and $35 \%$ canopy.

TPersonal communication

For each infiltration test we calculated the effective conductivity using an approximation to the Green-Ampt equation derived by $\mathrm{Li}$ et al. (1976),

$\mathrm{KE}=$ effective conductivity $(\mathrm{cm} / \mathrm{hr})$

$F R=$ final infiltration rate $(\mathrm{cm} / \mathrm{hr})$

$F=$ total infiltration at the final infiltration rate (CM)

$T=$ accumulated time corresponding to the final rate and infiltration amount (hr)

Since the studies contained various replications at each site, we used the mean site value for soil-ground cover, canopy cover, and the geometric mean effective conductivity which represents an area integrated value-for the analyses.

\section{Parameter Development}

Past research (Moore 1981) has shown that the wetting front capillary potential parameter is relatively insensitive in comparison with the hydraulic conductivity parameter. It was thus assumed that ground cover and canopy cover affect only the hydraulic conductivity parameters. Since rangeland conditions reflect long-term climate, cover, and land use patterns, we assumed that all bare soil is crusted and that the bare or covered soil under a canopy has a higher conductivity than the bare or covered soil in the interspace area. In addition, the covered soil has a higher effective conductivity than the uncovered soil surface whether under a canopy or in the interspace area. These assumptions reflect that canopy, ground cover, litter, or surface rocks reduce crust formation. Further, they enhance macroporosity caused by biotic activity and other processes especially in the soil under or around the litter rock soil interface.

We incorporated the canopy and ground cover effect into a simple weighting by the proportions of the unit area composed of canopy and open space and by the proportion of the canopy space and open space in which the soil surface was covered or bare. For the portion of unit area under canopy cover we estimate the effective conductivity parameter, $(\mathrm{KE})_{\mathrm{c}}$, as

$$
\mathrm{KE}_{\mathrm{c}}=(\mathrm{CF})[(\mathrm{BC} / \mathrm{CAN})(\mathrm{CRC})+\mathrm{A}(1-(\mathrm{BC} / \mathrm{CAN}))](\mathrm{K})
$$

and for the portion of the unit area outside of canopy cover we estimated the effective conductivity $\left(\mathrm{KE}_{\mathrm{O}}\right)$ as

$$
\mathrm{KE}_{\mathrm{O}}=[(\mathrm{BO} / \mathrm{OP})(\mathrm{CRC})+\mathrm{A}(1-(\mathrm{BO} / \mathrm{OP}))](\mathrm{K})
$$

where

$$
\begin{aligned}
\mathbf{K E}_{\mathrm{c}} & =\text { effective conductivity under canopy }(\mathrm{cm} / \mathrm{hr}) \\
\mathrm{KE}_{0} & =\text { effective conductivity outside of canopy }(\mathrm{cm} / \mathrm{hr}) \\
\mathrm{CF} & =\text { canopy factor } \\
\mathbf{B C} & =\text { bare area under canopy }(\%) \\
\mathrm{CAN} & =\text { canopy area }(\%) \\
\mathrm{OP} & =\text { open area outside canopy }(\%) \\
\mathrm{BO} & =\text { bare area in open space }(\%) \\
\mathrm{CRC} & =\text { crust factor (equation }[6]) \\
\mathrm{A} & =\text { macro-porosity factor } \\
\mathrm{K} & =\text { hydraulic conductivity of soil }(\mathrm{cm} / \mathrm{hr})(\text { equation }[5])
\end{aligned}
$$

Combining equations [8] and [9] for the total unit area consisting of canopy covered area (CAN) and open area (OP), we have

$$
\mathrm{KE}=(\mathrm{CAN}) \mathrm{KE}_{\mathrm{c}}+(\mathrm{OP}) \mathrm{KE} \text { 。 }
$$

or

$$
\begin{aligned}
\mathrm{KE}= & (\mathrm{CF})[(\mathrm{A})(\mathrm{CAN}-\mathrm{BC})+\mathrm{CRC}(\mathrm{BC})](\mathrm{K})+[(\mathrm{A})(\mathrm{OP}-\mathrm{BO})+ \\
& \mathrm{CRC}(\mathrm{BO})](\mathrm{K})
\end{aligned}
$$

The canopy factor (CF) and macroporosity factor (A) are the only unknown parameters in equation [11]. In the following sections estimators for these parameters will be developed.

\section{Canopy Factor}

The canopy factor (CF) is defined as the ratio of effective conductivity under canopy $\left(\mathrm{KE}_{\mathrm{c}}\right)$ to effective conductivity without canopy $\left(\mathrm{KE}_{\mathrm{nc}}\right)$.

The Hutten (1984) data set was chosen to develop the canopy factor because it covered a wide range of soil texture, ground cover, and canopy cover conditions (Table 1) and included infiltration runs with and without canopy. A geometric mean KE without canopy was determined for the 4 soils and used to determine CF for each of the 12 treatments. Using the data the following equation was developed relating canopy to CF 
$\mathrm{CF}=\quad \frac{\mathrm{KE}_{\mathrm{c}}}{\mathrm{KE}_{\mathrm{nc}}}=\left(1+0.96 \frac{\mathrm{CAN}}{100}\right) \mathrm{r}^{2}=0.88 \mathrm{n}=13$

where $\quad$ CAN $=$ canopy $(\%)$

\section{Macroporosity Factor}

The macroporosity factor $(A)$ in equation [11] is assumed to represent an enhancement of the infiltration potential of soil that is covered by rocks or litter (Mehan 1986). The Hutten (1984), Devaurs (1984) and Thurou (1985) data sets were chosen for evaluating the macroporosity factor because they covered a range of soil conditions including bulk density and ground cover conditions. Using the previously developed CF predictor equation [12] we solved equation [11] for a mean $A$ for each treatment and then using regression techniques related to $A$ to soil properties resulting in the following prediction equation:

$$
A=e^{(2.82-0.0998 A+1.94 B D)} r^{2}=.88 \quad n=41
$$

where

$$
\mathbf{S A}=\% \text { sand }
$$

$\mathrm{BD}=33 \mathrm{KPa}$ bulk density of fine earth soil $(<2 \mathrm{~mm}) \mathrm{g} / \mathrm{cm}^{3}$

In fitting equation [13], A was constrained to be greater than one because macroporosity was assumed to only increase hydraulic conductivity. Also, since the data did not include soils with less than $20 \%$ sand, and the form of equation [13] will produce extremely high A values for soils with less than $20 \%$ sand, we would limit the equation to a maximum $A$ value of 18 which was the largest value in the data set.

\section{Testing}

We used the Lane et al. (1987), Ward and Wood (1982), Williams (1969) and Wood data sets (Table 1) to test equations [11, 12 and 13] because these data sets were not used in parameter development. Since each data set had different run durations, we predicted the final infiltration rate, total infiltration amount, and the average measured antecedent soil moisture using the Green-Ampt infiltration model equation [1] from equations $[3,4,5,6,11,12$, and 13]. The predicted infiltration values were compared with the mean and standard deviations of the observed values for each site. The results of the testing are summarized in Table 2.

Lane et al. (1987) reported infiltration results from studies on large rangeland plots in Arizona and Nevada under simulated rainfall. At each of the 5 sites they had 2 plots evaluated spring and fall for several consecutive years with the following designated treatments:

natural - natural site conditions

clipped - all vegetation cut and removed

bare - canopy and nonembedded (>5 mm) surface matrial removed

They reported mean final infiltration rates and amounts for the 30 minute very wet run at each site. As they did not measure bulk density it was calculated with the equation reported by Rawls (1983). Rock, litter, bare soil, under and outside canopy were measured for each AZ plot. The proportion of bare ground beneath the canopy and outside of the canopy was estimated for

\begin{tabular}{|c|c|c|c|c|c|c|c|}
\hline \multirow[b]{3}{*}{$\begin{array}{l}\text { Study } \\
\text { reference }\end{array}$} & \multirow[b]{3}{*}{ Site } & \multirow[b]{3}{*}{ Treatment } & \multirow[b]{3}{*}{ Sample size } & \multicolumn{4}{|c|}{ Infiltration final rate and volume } \\
\hline & & & & \multicolumn{2}{|c|}{ Measured } & \multicolumn{2}{|c|}{ Predicted } \\
\hline & & & & $\begin{array}{c}\text { Final rate* } \\
\mathrm{cm} / \mathrm{hr}\end{array}$ & $\begin{array}{l}\text { Volume* } \\
\mathrm{cm}\end{array}$ & $\begin{array}{l}\text { Final rate } \\
\mathrm{cm} / \mathrm{hr}\end{array}$ & $\begin{array}{l}\text { Volume } \\
\mathrm{cm}\end{array}$ \\
\hline \multirow[t]{5}{*}{$\begin{array}{l}\text { Lane et al. } \\
\text { (1987) }\end{array}$} & Bernardino & $\begin{array}{l}\text { Natural } \\
\text { Clipped } \\
\text { Bare }\end{array}$ & $\begin{array}{l}8 \\
8 \\
8\end{array}$ & $\begin{array}{l}3.53 \pm 0.77 \\
2.10 \pm 0.75 \\
1.37 \pm 0.62\end{array}$ & $\begin{array}{r}1.96 \pm 0.82 \\
1.24 \pm 0.65 \\
.73 \pm 0.60\end{array}$ & $\begin{array}{l}3.87 \\
2.69 \\
1.79\end{array}$ & $\begin{array}{l}2.19 \\
1.67 \\
1.21\end{array}$ \\
\hline & Cave & $\begin{array}{l}\text { Natural } \\
\text { Clipped } \\
\text { Bare }\end{array}$ & $\begin{array}{l}8 \\
8 \\
8\end{array}$ & $\begin{array}{l}2.63 \pm 0.70 \\
1.50 \pm 0.62 \\
1.16 \pm 0.60\end{array}$ & $\begin{array}{r}1.49 \pm 0.77 \\
.88 \pm 0.80 \\
.65 \pm 0.65\end{array}$ & $\begin{array}{l}1.96 \\
1.81 \\
1.08\end{array}$ & $\begin{array}{l}1.32 \\
1.23 \\
0.81\end{array}$ \\
\hline & Hathaway & $\begin{array}{l}\text { Natural } \\
\text { Clipped } \\
\text { Bare }\end{array}$ & $\begin{array}{l}8 \\
8 \\
8\end{array}$ & $\begin{array}{l}3.16 \pm 0.99 \\
1.93 \pm 0.85 \\
1.24 \pm 0.52\end{array}$ & $\begin{array}{r}1.72 \pm 0.85 \\
1.04 \pm 0.80 \\
.74 \pm 0.58\end{array}$ & $\begin{array}{l}2.65 \\
2.16 \\
1.32\end{array}$ & $\begin{array}{l}1.62 \\
1.38 \\
0.92\end{array}$ \\
\hline & Mercury & $\begin{array}{l}\text { Natural } \\
\text { Clipped } \\
\text { Bare }\end{array}$ & $\begin{array}{l}4 \\
4 \\
4\end{array}$ & $\begin{array}{r}2.05 \pm 0.48 \\
.73 \pm 0.55 \\
.48 \pm 0.30\end{array}$ & $\begin{array}{r}1.08 \pm 0.98 \\
.50 \pm 0.70 \\
.25 \pm 0.46\end{array}$ & $\begin{array}{l}1.97 \\
1.93 \\
1.04\end{array}$ & $\begin{array}{r}1.32 \\
1.29 \\
.77\end{array}$ \\
\hline & Area 11 & $\begin{array}{l}\text { Natural } \\
\text { Clipped } \\
\text { Bare }\end{array}$ & $\begin{array}{l}4 \\
4 \\
4\end{array}$ & $\begin{array}{l}3.37 \pm 1.30 \\
2.94 \pm 0.75 \\
1.63 \pm 0.48\end{array}$ & $\begin{array}{r}1.85 \pm 0.75 \\
1.75 \pm 1.00 \\
.98 \pm 0.48\end{array}$ & $\begin{array}{l}2.55 \\
2.18 \\
1.31\end{array}$ & $\begin{array}{l}1.60 \\
1.42 \\
0.94\end{array}$ \\
\hline \multirow[t]{2}{*}{$\begin{array}{l}\text { Williams } \\
\text { (1969) }\end{array}$} & $\begin{array}{l}\text { Intermediate } \\
\text { sandy soils } \\
(30-45 \%)\end{array}$ & & 8 & $4.4 \pm 0.98$ & $1.88 \pm 0.59$ & 2.25 & 1.71 \\
\hline & $\begin{array}{l}\text { High sand soils } \\
(50-65 \%)\end{array}$ & & 8 & $4.98 \pm 2.61$ & $1.61 \pm 0.82$ & 5.32 & 3.19 \\
\hline Wood & & $\begin{array}{l}\text { Dry } \\
\text { Wet }\end{array}$ & $\begin{array}{l}24 \\
21\end{array}$ & $\begin{array}{l}6.94 \pm 0.32 \\
4.60 \pm 0.45\end{array}$ & $\begin{array}{l}6.28 \pm 0.12 \\
5.34 \pm 0.20\end{array}$ & $\begin{array}{l}7.08 \\
5.66\end{array}$ & $\begin{array}{l}6.21 \\
5.28\end{array}$ \\
\hline \multirow[t]{3}{*}{$\begin{array}{l}\text { Ward and } \\
\text { Wood (1982) }\end{array}$} & Grazing & $\begin{array}{l}\text { Dry } \\
\text { Wet }\end{array}$ & 6 & $\begin{array}{l}8.56 \pm 1.13 \\
7.63 \pm 1.85\end{array}$ & $\begin{array}{l}5.91 \pm 0.73 \\
4.25 \pm 0.80\end{array}$ & $\begin{array}{l}7.62 \\
7.50\end{array}$ & $\begin{array}{l}5.90 \\
4.34\end{array}$ \\
\hline & Sagebrush & $\begin{array}{l}\text { Dry } \\
\text { Wet }\end{array}$ & 5 & $\begin{array}{l}6.35 \pm 2.21 \\
5.81 \pm 1.79\end{array}$ & $\begin{array}{l}4.15 \pm 1.10 \\
2.96 \pm 0.73\end{array}$ & $\begin{array}{l}7.88 \\
4.83\end{array}$ & $\begin{array}{l}4.81 \\
2.79\end{array}$ \\
\hline & Pinyon/Juniper & $\begin{array}{l}\text { Dry } \\
\text { Wet }\end{array}$ & 5 & $\begin{array}{l}7.50 \pm 2.29 \\
7.30 \pm 1.65\end{array}$ & $\begin{array}{l}4.6 \pm 1.53 \\
3.86 \pm 0.72\end{array}$ & $\begin{array}{r}11.3 \\
9.5\end{array}$ & $\begin{array}{l}6.20 \\
5.00\end{array}$ \\
\hline
\end{tabular}

Table 2. Summary of test results.

- \pm value is the standard deviation for each measured mean. 
the NV sites. Soil rock was estimated from their soil report.

Table 2 compares the predicted Green-Ampt final infiltration rates and total infiltration amount with the measured mean final infiltration rate and amount at each site and treatment. As shown in Table 2, predictions for all sites except Mercury bare and clipped were within \pm 1 standard deviation of the measured mean. Since Lane's sites had very high sand $(>65)$ the macroporosity factor derived from equation [11] becomes 1; thus this study gives an independent test of the crust and canopy factors in equation [11]. The natural plots test our procedures for predicting the canopy and crust factors. The clipped plots test our procedure for predicting surface cover factors, while the bare soil plots tested our procedures for predicting crusted soil hydraulic conductivity. The bare plots independently tested the crust factor since the soil surface was primarily bare.

Williams (1969) conducted a number of infiltration tests in Utah on pinyon juniper sites in 1967 and 1968 . We stratified the Williams data into 2 groups, intermediate sand and high sand, and the results are shown in Table 2 . The predicted rates and amounts are within the $95 \%$ confidence intervals; however, the confidence intervals are very wide and absolute error is up to $100 \%$ for the high sand total infiltration. The high sand tests the effect of the canopy and crust factors while the intermediate sand soils incorporates the crust, canopy and macroporosity factors.

Wood conducted infiltration tests on a clay loam soil in New Mexico. We ran predictions on the dry and wet treatments; all predictions except the dry final rate, which could be a result of antecedent soil water conditions, were within the $95 \%$ confidence intervals.

Ward and Wood (1982) conducted 4 replicate infiltration tests at 17 sites. We subdivided the sites according to cover (grazing sagebrush and pinyon juniper) and dry or wet treatments. The predicted final infiltration rates and amounts were within $95 \%$ confidence intervals; however, the standard deviation of the means are very large (Table 2). The numerical error in the pinyon/juniper estimates are $30-50 \%$ high.

Regression analysis was performed on the mean measured final infiltration rate versus the predicted final infiltration rate given in Table 2 and the mean measured total infiltration volume versus the predicted infiltration volume given in Table 2 . This analysis indicated that the intercepts and slopes were not significantly different from 0 and 1 , respectively, at the 0.05 significance level. This indicates that the model predicts accurate and unbiased estimates of the mean final infiltration rate and total infiltration volume.

\section{Conclusion}

A method was developed for incorporating readily available rangeland soil, surface cover, and canopy cover properties into the predictions of the Green-Ampt hydraulic conductivity parameter. The method was evaluated on ten diverse independent rangeland areas and generally predicted the mean final infiltration rate and amount within one standard deviation of the measured mean, indicating that our assumptions and parameter estimators are acceptable. Since the development and testing of data sets did not include high silt soils and grass-dominated vegetative cover, using the proposed procedure may yield questionable results. Also, the proposed procedure yields one of the first quantitative methods for evaluating the relative effects of rangeland treatments on infiltration.

\section{Literature Cited}

Brakensiek, D.L., and W.J. Rawls. 1983. Agricultural management effects on soil water processes. Part II. Green and Ampt parameters for crusting soils. ASAE Trans. 26:1753-1757.

Brakenaiek, D.L., W.J. Rawls, and G.R. Stephenson. 1986. Determining the saturated hydraulic conductivity of soil containing rock fragments. Soil Sci. Soc. of Amer. 50:834-835.

Devaurs, M. 1984. Variability studies within large runoff plots on rangelands. M.S. Thesis, Utah State Univ., Logan, Utah.

Gifford, G.F. 1984. Vegetation allocation for meeting site requirement. Development Strategies for Rangeland Management. Westview Press, p. 35-116.

Hutten, N.C. 1984. Infiltration characteristics of plowed and unplowed native rangeland soils near Bear Lake, Utah. M.S. Thesis, Utah State Univ., Logan, Utah.

Hutten, N.C., and G.F. Gifford. 1988. Using the Green and Ampt infiltration on native and plowed rangeland soils. J. of Range Manage. 41:159-162.

Lane, L.J., J.R. Simanton, T.E. Hakonson, and E.M. Romney. 1987. Large plot infiltration studies in desert and semidesert rangeland areas of the southwestern USA. Proc. Internat. Conf. on Infiltra. Devel. and Appl., Univ. Hawaii Water Resourc. Res. Cen., Honolulu, HI, p. 365-376.

Lee, H.W. 1983. Determination of infiltration characteristics of a frozen palouse silt from soil under simulated rainfall. Ph.D. Diss., Univ. Idaho, Moscow.

L, Ruh-Ming, M.A. Stevens, and D.B. Simons. 1976. Solutions to GreenAmpt infiltration equation. Proc. ASCE 102(IR2):239-248.

Mehan, D. 1986. Effects of coarse fragments on infiltration rates and Green and Ampt parameters. M.S. Thesis, Utah State Univ., Logan.

Moore, 1.D. 1981. Effect of surface sealing on infiltration. Trans. of the ASAE 24:1546-1561.

Rawls, W.J. and O. Baumer. 1989. Calibration of modified KozencyCarman saturated hydraulic conductivity equation. ASCE J. of Irrigation and Drainage (in press).

Rawls, W.J. and D.L. Brakendek. 1985. Prediction of soil water properties for hydrologic modeling. p. 293-299. In: E.B. Jones and T.J. Ward (eds.) Watershed Management in the Eighties. Proc. Symp. sponsored by Comm. on Watershed Management, Irrigation and Drainage Div., ASCE. ASCE Convention, Denver, Colo. 30 April-1 May.

Rawls, W.J. 1983. Estimating soil bulk density from particle size analysis and organic matter content. Soil Sci. 135:123-125.

Rawls, W.J. and D.L. Brakensiek. 1983. A procedure to predict Green and Ampt infiltration parameters. Proc., ASAE Conf. on Advances in Infiltration, Chicago, Ill. p. 102-112.

Thurou, T.E. 1985. Hydrologic relationship with vegetation and soil as affected by selected livestock grazing systems and climate on the Edwards Plateau. Ph.D. Thesis, Range Sci. Dep., Texas $\mathbf{A}$ and $\mathbf{M}$, College Station.

Ward, T. and K. Wood. 1982. Evaluation of rangeland best management practices to control non-point pollution. Unpublished research report, Department of Civil Engineering and Animal and Range Science, New Mexico State Univ., Las Cruces.

Williams, G. 1969. Analysis of hydrologic, edaphic, and vegetation factors affecting infiltration and erosion on certain treated and untreated Pinyon-Juniper sites. Ph.D. Thesis, Range Science Dep., Utah State Univ., Logan. 